\title{
Patterns of Power Relations in Governing Street Vendors A Case Study of Bandung, Indonesia
}

\author{
Caroline Paskarina \\ Department of Political Science, \\ University of Padjadjaran \\ Bandung, Indonesia \\ caroline.paskarina@unpad.ac.id \\ Rina Hermawati \\ Department of Anthropology, \\ University of Padjadjaran \\ Bandung, Indonesia \\ rina.antrop@gmail.com
}

\author{
Selly Riawanti \\ Department of Anthropology, \\ University of Padjadjaran \\ Bandung, Indonesia \\ selly_riawanti@unpad.ac.id \\ Budiawati Supangkat \\ Department of Anthropology, \\ University of Padjadjaran \\ Bandung, Indonesia \\ budiawati_supangkat@unpad.ac.id
}

\begin{abstract}
This paper focuses on the discussion of power relations in governing of street vendors (Pedagang Kaki Lima or PKL) in Bandung. The objective is to identify the pattern of power relations between the government and street vendors as a consequence of the street vendors' governing approach applied in Bandung. The efforts to maintain their existence on the street is done through various actions, including self-organization, resistance, negotiation, accommodation and building social network, therefore governing the street vendors needs to reveal the actors involved in policy implementation and how power relations among actors is exercised to influence the policy implementation. This research applies qualitative approach with case study research strategy. The results found the existence of 4 (four) patterns of power relations that emerged as a response to the implementation of policy in governing street vendors implemented by the Government City of Bandung. These patterns indicated other strategic actors and their role in The first pattern, involves associations of street vendors as mediators in negotiating problems they face, the second pattern, street vendors use the local community of street vendors as mediators, the third pattern is street vendors using NGOs as mediators, and the forth pattern is through local organizations formed by sub district government to mediate street vendors and government. The four patterns of power relations in governing street vendors indicate that the government as the authority in governing street vendors actually do not have a direct relationship with street vendors. The existence of mediators, in the form of associations, communities, and society organizations, became a strategic actor that determine the successful implementation of the policy of governing street vendors
\end{abstract}

Keywords: power relations; street vendors; governing patterns

Corresponding author: Caroline Paskarina

\section{INTRODUCTION}

This paper focuses on the discussion of power relations in governing of street vendors (Pedagang Kaki Lima or PKL) in Bandung. The objective is to identify the pattern of power relations between the government and street vendors as a consequence of the street vendors's governing approach applied in Bandung. As a city that emphasizes its economic activity on creative economy-based tourism, the existence of street vendors becomes inevitable. The existence of street vendors is a dilemma because on the one hand, it becomes the driving force of the economy in the informal sector, but on the other hand is also often a disruption to the order of the city.

The difficulty of finding location that suitable for street vendors is allegedly happening in almost all the governing activities. The location offered by the government is generally rejected by street vendors due to the lack of access to the location; government has not built adequate facilities and infrastructure of selling; the lack of consumers in location, location is not in accordance with the majority of commodities traded and so forth. The problem of new location for street vendors eventually cause conflict between street vendors and the city government. Among the street vendors they are often internal conflicts in addressing the relocation policy. Some street vendors are willing to move to a relocation site with some terms such as granting soft loans and free rent for a certain period of time. On the other hand, some other street vendors refuse relocation and propose a structuring policy in the form of uniform tents on their location.

The government generally translates the regulating of street vendors as an effort to relocate street vendors or limit their sales time. In the city of Surabaya, the arrangement of street vendors is done by establishing street vendors centres, such as street vendors' Gayungan Center, Urip Sumoharjo, Bungkul Park, Kali Ketabang, Achievement Park, Gunungsari 
Ornamental Fish, Benowo, Bulak, and Karah. The phenomenon of policy change to regulate street vendors is not only happening in Indonesia. For example, in Bangkok there are at least four models of street vendors regulators, namely: zone systems, ie certain areas allocated to street vendors, trading time systems, such as weekend and night markets, mall or center integration shopping, and giving street vendors in pedestrian, parks and sidewalks, with certain conditions.

The city of Bandung is interesting to study considering Bandung is the only city that regulates the street vendors zoning system and applies fines for buyers in red and yellow zones. In this donation system is regulated on the division of selling locations of street vendors consisting of 3 zones, namely red zone (location must not be street vendors), yellow zone (locations that can be opened and closed based on time and place) and green zone (location allowed to trade for street vendors). Bandung City Government issued a special regulation on street vendors, namely Local Regulation No. 4 of 2011 on the Development and Regulatory of Street Vendors that largely contain spatial street vendors, implementing policy organizations, limiting the number of street vendors and consumer behavior approach. However, the policy has not been effective enough to overcome the problem of street vendors. Proven from 8 points location of street vendors which is planned to finish arranged in 2015 that is Dalem Kaum, Kepatihan, Dewi Sartika, Area of Alun-alun, Merdeka, Gasibu, Tegal Lega and Cicadas until 2016 only able to regulate four locations, that is Alun-Alun, Merdeka Street, Kepatihan, and Gasibu.

Although the existence of street vendors is usually treated as disturbance to public order, nevertheless street vendors still play an important role to support economic activities especially when financial crisis damaged the formal structure of economy. Many of the retrenched workers preferred to, and did, remain in the city and put to use their latent business and entrepreneurial skills to practice by establishing their own informal businesses and become the street vendors [1]. Suggests that policy-makers should recognize the role and importance of the informal sector, including street vending business, as a microenterprise that deserves support and promotion such as offering training and secure areas.

However, the old generation of street vendors is vulnerable, often passive, in the face of market change and harassment from powerful players (officials, street mafia). On the other hand, the new generation of street vendors locates their vending businesses in strategic areas in Bandung and tourist areas and has to pay high rent for those private pitches. Thus, they are more adaptive to official rules and regulations and avoid harassment from powerful players and incidences of corruption situations. It is mostly external forces that prompt both sets of vendors to take up operations, either as an attempt to alleviate genuine poverty or to take advantage of emergent entrepreneurial opportunities. Tolerance of corruption by officials and criminals and repression of vendors maintains socio-economic inequalities initially created by the external forces.

Most studies, as described in [2], have a normative vision of informal economies as offering poor quality of employment, low levels of income and poor business profile and performance, street vending businesses provide little profit and are unable to lift poor people out of chronic poverty. In addition, street vending businesses are involved in illegal affairs starting from encroachment of public pavement, selling fake and poor quality products and inducement of mafia and corruption and represent undesirable aspects of commerce such as lack of hygiene. Policy implications from these studies focus on job creation and employment provision in an organized, well-managed, stable, productive and growing formal sector to increase the economic opportunities for the poor, including street vendors. Street vending employment is only considered a means of acquiring the skills and experience necessary to gain access to employment in the formal sector. Following exclusion recommendations, city authorities consider street vending businesses as symbols of underdevelopment. As a consequence, there is a desire either to sweep the vendors out of sight or to eliminate their presence altogether. Their own government officials harass street vendors where these vendors located their business following the distribution of their customers. Another approach employed in many cities is to regularize the activities of business vendors and bringing their activities within the scope of city authorization, for example by designating some pavement areas to accommodate street vending businesses, reduce the number of street vendors in temporary areas and outside designated areas. However, there remain difficulties in reconciling different interests in public uses and so street spaces constitute conflict zones or exclusive and elite city locations where street vending is generally barred [3][4]. In addition, without legal status, street vendors paid illegal compensation commissions or unlawful protection fees to third parties in order to secure their business [5].

The third approach uses social inclusion as a means of empowering participation and becoming embedded within their community and within the wider social and economic relations of the household. Having choice and being in control are important characteristics of inclusion [6] and the contribution made by microbusinesses paves the routes to social inclusion. Some Asian cities have taken the social inclusion approach by acknowledging the role and contribution of street vendors and enabling their registratiom [6]. Street vendors benefit from training, access to credit and facilities improvement. During the Asian economic crisis, employment generation in this sector significantly reduced economic pressures [7].

This paper will not highlight the implementation of the policy, but wishes to reveal how the pattern of power relations emerges in response to the policy. The efforts to maintain their existence on the street is done through various actions, including self-organization, resistance, negotiation, accommodation and building social network [8][9][10][11][12][13]. Therefore, governing the street vendors needs to reveal the actors involved in policy implementation and how power relations among actors is exercised to influence the policy implementation.

States that the policy about street vendors is more a structural dominance of the rulers and owners of capital so that the interests of street vendors tend not accommodated 
[14]. To that end, the state needs to share roles and powers with autonomous social forces in society in order to create synergy in public policy. The study does not explicitly address the division of the intended role. This paper wants to fill the void of discussion about power relation by expressing how the pattern of power relation in structuring street vendors, namely by showing who actors who play a role in structuring street vendors, who mediator between street vendors with the City Government, and how the style of power relations that formed between the parties.

\section{RESEARCH METHOD}

This research will use qualitative approach with case study research strategy. A case study is an empirically and analytically focused study on a particular phenomenon to produce deep, detailed and holistic studies. Researchers conducted observations on coverage of street vendors in the city of Bandung through the media on line during the year 2013-2016 and conducted a preliminary study to understand the characteristics of socio-economic street vendors in the city of Bandung. Based on this preliminary study, the author found an interesting location to be studied. The location of this study is based on the diversity of street vendors affiliations with the community organization and/or non-government organizations (NGOs) involved in governing street vendors.

Data is collected through interviews to association managers or associations of street vendors, Local Civil Service Police Unit (Satuan Polisi Pamong Praja or Satpol PP), Department of Cooperatives of Small and Medium Enterprises and Department of Trade Industry, and Regional Development Planning Agency. Broadly speaking, the topics discussed regarding the characteristics of street vendors in the research location, the affiliation of street vendors with the organization of street vendors with the community organization and/or NGOs involves with the street vendors, and the way street vendors react to the problems that arise when the policy arrangement of street vendors implemented on them. In addition to interviews, also conducted observations to know directly the activities of street vendors in selling, the atmosphere and the interaction they build and the strategies they develop to maintain its existence in public places.

To analyze the field data, researchers make field notes containing the results of participant observation and interviews with informants to then be analyzed based on the relationship between categories and finally generate conclusions.

\section{RESULT AND DISCUSSION}

Most of the street vendors in Bandung City are low educated, have small capital, and come from outside Bandung who are still productive age (25 - 54 years old). They live in city slums. But between street vendors from Bandung and outside Bandung, there are differences in residential sharing strategies. Local street vendors tend to share residence with extended families, such as grandchildren and daughters. Meanwhile, most street vendors live by renting a house/room with relatives, neighbours (sekampung), or friends who also do similar activities. Staying close to relatives or friends is also a way to foster social networking. Most street vendors recognize the importance of social networks to start, sustain and develop their business.

The regulation on security, order, and cleanliness in city prohibits all trading activities in public places causes street vendors to become illegal businesses that must be governed. As a result, street vendors are unable to access any assistance from the city government either in the form of financial aid or skill development. This condition causes the street vendors to feel marginalized. In addition, street vendors cannot access capital loans from formal financial institutions such as banks. This difficulty in accessing capital causes street vendors to rely on moneylenders. Street vendors' access to capital and business assistance was only opened in 2011 after the enactment of Regulation No. 4 of 2011 on Development and Regulatory of Street Vendors.

Another difficulty facing street vendors is competition with fellow street vendors, but who have greater capital support as it is part of a large corporate sales chain. The existence of these 'modern' street vendors is a competitor for traditional street vendors, who do not have large capital. The legitimacy of traditional street vendors towards the presence of these 'modern' street vendors can be understood as the 'modern' hawkers are the rich / wealthy hands of the rich who use the principle of selling street vendors so that the 'modern' hawkers are viewed as people of different classes with traditional street vendors who identify themselves as poor.

On the other hand, there are those who take advantage of the existence of street vendors in public places. Data on retributions paid by street vendors indicate that street vendors levies are a great potential for city government revenues. Unfortunately, this potential revenue does not go into the government's treasury, but goes into the "pockets" of government officials and non-governmental organizations who are attracting levies in return for protection against street vendors. The existence of the parties who benefit from the existence of street vendors is causing the problem of street vendors difficult to overcome. Not only certain government apparatus and non-governmental organizations that benefit economically from the existence of street vendors. But the formal sector also makes a profit through products sold by street vendors. This shows that there are other actors who have an interest in maintaining the existence of street vendors.

The results found the existence of 4 (four) patterns of power relations that emerged as a response to the implementation of policy in governing street vendors implemented by the Government City of Bandung. The first pattern, street vendors use associations of street vendors as mediators in negotiating problems they face, such as when dealing with new street vendors or with thugs who ask for 'security money' at the location of selling. The association of street vendors is a liaison to the Government, especially with the Local Civil Service Police Unit, and jointly controls the disturbance experienced by the street vendors.

The second pattern, street vendors use the local community of street vendors as mediators. The local community of street vendors are different from the association of street vendors because they are naturally formed from street vendors in the same location, and have historical links to the development of 
street vendors in those locations. Because there is already a community of its own, the existence of the street vendors' association actually become outsiders who tend to be less trusted. In this relationship pattern, trust factor becomes capital that determines which side is used by street vendors to fight for their aspiration or when trying to solve the problems arising from the policy of arrangement.

The third pattern is street vendors using NGOs as mediators. In this pattern, street vendors relationships with NGOs take place dynamically and tend to lead to transactional relationships. Street vendors who need protection when dealing with government officials who curb, will ask for mediation with the help of NGOs. However, when the situation is secure, the existence of such a social organization is not necessary. In fact, NGOs that do not provide optimal protection will be abandoned by street vendors who will seek new NGOs as a substitute.

The forth pattern is through local organizations formed by sub district government to mediate street vendors and government. The organization at the sub-district level is formed by the sub-district government with the aim that there is participation from the local community in disciplining street vendors. By placing the organization at the sub-district level, the control path is shortened because the presence of every street vendor can be directly monitored by organizations at the sub-district level.

\section{CONCLUSION}

The four patterns of power relations in governing street vendors indicate that the government as the authority in governing street vendors actually do not have a direct relationship with street vendors. All efforts of governing street vendors take place in the dynamics of relationship between vendors, mediators, and government officials. The existence of mediators, in the form of associations, communities, and society organizations, became a strategic actor that determine the successful implementation of the policy of governing street vendors. On the other hand, however, the existence of these strategic actors moves more in the transactional relationship than the strengthening of bargaining power of street vendors. Therefore, the character of policy implementation in governing street vendors is more directed to the compromistic rather than solvable in solving the problem of street vendors and order in urban informal sector.

\section{REFERENCES}

[1] M.A. Chen, "Rethinking the informal economy: linkages with the formal economy and the formal regulatory environment". DESA Working Paper No. 46), United Nation, Department of Economic and Social Affairs, 2007. $<$ http://www.un.org/esa/desa/papers $>$ Accessed 29.01.09.
[2] C. Manepong \& J. C. Walsh, "(A New Generation of Bangkok Street Vendors) : Economic Crisis as Opportunity and Threat", Cities 34, 2013. pp. 37-43.

[3] R. Bromley, "Street vending and public policy: A global review". International Journal of Sociology and Social Policy, 20(1/2), 2000,pp.1-29,.

[4] J. C. Cross, "Street vendors, modernity and postmodernity: Conflict and compromise in the global economy". International Journal of Sociology and Social Policy, 20(1/2), 2000,pp.30-52.

[5] F. Nauman, Friedrich Naumann Foundation, Cost and restrictions to trade: Street vending in Bangkok. Bangkok, 2007.

[6] J. Gray, Inclusion: A radical critique. In Askonas, Peter and Stewart, Angus, (Eds.), Social inclusion: possibilities and tensions, 2000,pp. 1936.

[7] S.K. Bhowmik, "Street vendors in Asia: Review". Economic and Political Weekly, 1, 2005, pp.2256-2264.

[8] S. Pena, "Informal Markets: Street Vendors in Mexico City". Habitat International Volume 23 Nomor 3, 1995, pp. 363-372.

[9] Alisjahbana, Marginalization of The Urban Informal Sector (Marginalisasi Sektor Informal Perkotaan), Surabaya : ITS Press, 2006

[10] R. Setia, Ekonomi Informal Perkotaan. Bandung: Laporan Penelitian Akatiga, 2008.

[11] E. Siswono, The Resistance and Accommodation: A Study of Relations between Street Vendors, Thugs, and Officers in Depok, West Java(Resistensi dan Akomodasi : Suatu Kajian Tentang HubunganHubungan Kekuasaan Pada Pedagang Kaki-Lima (PKL), Preman dan Aparat di Depok, Jawa Barat). Disertasi Fisip UI. Jakarta, 2009.

[12] A.A. Mustafa, The Social Transformation Model of The Informal Sector of History, The Theory and Praxis of street Vendors (Model Transformasi Sosial Sektor Informal Sejarah, Teori dan Praksis Pedagang Kaki Lima). Malang:In-Trans Publishing, 2008.

[13] U. Aisyah, U. The Obstinated Street Vendors in Eats Java(Pedagang Kaki Lima Membandel di Jawa Timur), Jurnal Masyarakat dan Kebudayaan Politik Volume 25 No 1, 2012, pp. 47-55.

[14] A. Hayat, The Policy of Sreet Vendors : Structural Dominance in National Development (Kebijakan tentang Pedagang Kaki Lima (PKL) : Dominasi Struktural dalam Pembangunan Nasional), Jurnal Ilmu Administrasi Negara Tahun 2010 Nomor 1, 2010, pp. 30-38. 